\title{
Ankara Büyükşehir Belediyesinin E-Belediye Uygulamalarının Kamu Bürokrasisinin Sorunları Bağlamında İncelenmesi
}

\author{
DOI: $10.26466 /$ opus. 846600 \\ $*$ \\ Asime Dilara Erdem* - Filiz Tufan Emini** \\ * Lisansüstü Öğrenci, Çanakkale Onsekiz Mart Üniversitesi LES, Çanakkale- Türkiye \\ E-Posta: asimedilaraerdem@gmail.com ORCID: $\quad$ 0000-0002-7422-7473 \\ ** Doç. Dr. Çanakkale Onsekiz Mart Üniversitesi Biga IIIBF, Çanakkale- Türkiye \\ E-Posta: filizemini@hotmail.com \\ ORCID: $\quad$ 0000-0002-9040-0811
}

$\ddot{\mathbf{O z}}$

Devletlerin işleyiş şekli olarak genel ifadesini bulan bürokrasi, devlet yapısı gelişip büyüdükçe hantallaşmış ve birçok sorunu da beraberinde getirmiştir. Bürokrasinin sorunlarının ise daha yoğun hissedilir olması teknolojinin gelişmesiyle olmuştur. 21. yüzyılda teknolojinin gelişmesiyle birlikte dünya hem ekonomik hem sosyolojik hem de yönetim açısından büyük değişimler geçirmeye başlamıştır. Gerek devletlerin merkezi yönetimleri gerek yerel yönetimler bu dönüşümden etkilenmiştir. Bürokrasinin kök salmış sorunlarının çözülebilmesi için ortaya yeni yönetim anlayışları çıkmıştır. Merkezi yönetimin yetkilerini sinırlayarak yerel yönetimlere daha fazla yetki vermeyi amaçlayan yapısı ve bürokrasinin sorunlarını çözmeye çalışan bu yeni yönetim anlayışı teknolojiyi bürokrasiye entegre ederek vatandaşların bürokratik sorunlara maruz kalmadan hizl hizmet alabilmesinin önünü açmakta, devleti ya da yönetim mekanizmaların daha şeffaf, hesap verebilir ve hizmet odakl olmaya zorlamaktadır. Bu bağlamda çalışmanın amacı, yönetişimin en kolay uygulanabilir olduğu yerel yönetim birimlerinden belediyelerin bilişim teknolojilerini kullanarak halk ile arasındaki hangi bürokratik engelleri kaldırdığııı tespit etmeye çalışmaktır. Buna göre çalışma özelinde Ankara Büyükşehir Belediyesi seçilmiş ve belediyenin mevcut internet sitesi incelenmiş, bilişim teknolojisi ile halkın hangi ihtiyaçlarına hızla cevap verdiği, bürokrasinin hangi sorunların ortadan kaldırdığı belirlenmeye çalışılmıştır.

Anahtar Kelimeler: Teknoloji, e-devlet, e-belediye, bürokrasi, küreselleşme 


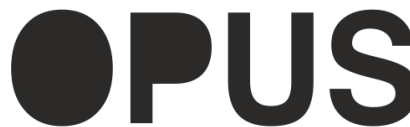

Uluslararası Toplum Araştırmaları Dergisi International Journal of Society Researches
E-ISSN: 2528-9535

Yıl Year: 11

Cilt Volume: 18

Sayı Issue: Yönetim ve Organizasyon Özel Sayısı

Temmuz July 2021

Makalenin Geliş Tarihi Received Date: 24/12/2020

Makalenin Kabul Tarihi Accepted Date: 08/06/2021

\title{
Investigation of Ankara Metropolitan Municipality's E-Municipality Applications in the Context of Public Bureaucracy Problems
}

$*$

\begin{abstract}
Bureaucracy, which finds general expression as the functioning of states, became cumbersome as the state structure developed and grew and brought many problems with it. With the development of technology, the problems of the bureaucracy were felt more intensely. With the development of technology in the 21st century, the world has begun to undergo great changes both economically, sociologically and in terms of management. Both the central governments of the states and local governments were affected by this transformation. New management approaches have emerged in order to solve the rooted problems of the bureaucracy. This new management approach, which aims to give more authority to local governments by limiting the powers of the central government and trying to solve the problems of the bureaucracy, integrates technology into the bureaucracy, paving the way for citizens to get fast service without being exposed to bureaucratic problems, making the state or management mechanisms more transparent, accountable and service-oriented. forcing. In this context, the aim of the study is to try to determine which bureaucratic barriers between the municipalities and the public by using information technologies from the local government units where governance is most easily applicable. Accordingly, Ankara Metropolitan Municipality was selected for the study, and the existing website of the municipality was examined, and it was tried to determine which needs of the public quickly responded to with information technology, which problems the bureaucracy was or aims to eliminate.
\end{abstract}

Keywords: Technology, e-government, e-municipality, bureaucracy, globalization 


\section{Giriş}

Bürokrasi genel olarak devlet örgütlenmesini ve personelini ifade ederken, halkın gözündeki bürokrasi tamamen katı hiyerarşilerden ve evrak yığınlarından meydana gelen bir yapıdır. Devletin yapısı içindeki kurumların yarattığı hiyerarşi ile kırtasiyecilik artmakta hem hizmet veren hem de hizmet alan açısından zaman kaybına neden olmaktadır.

Devlet yönetiminin daha iyi işleyebilmesi için birçok bürokrasi kuramı oluşturulmuştur. Ancak hepsinin de kendisine göre handikapları bulunmaktadır. Çalışma boyunca diğer bürokrasi kuramlarına değinilse de genel olarak Weberyan bürokrasi ele alınacak ve sorunlar onun çerçevesinde belirlenecektir. Yaşanan sorunlar, Weber'in ideal tip bürokrasi anlayışı dahil olmak üzere hiçbir tipin uygulamada sorunsuz işleyemeyeceğinin göstergesi olmuştur. 21. yüzyılda dünyada internetin icadı ile başlayan teknolojik süreç bugün hayal dahi edemediğimiz noktalara ulaşmıştır. Teknoloji ve küreselleşme dünyayı bir köye dönüştürmüştür. Teknolojinin gelişmesi ile birlikte devletler arasındaki sınırlar kalkmış, iletişim kurmak kolaylaşmıştır. İletişim ağlarının gelişmesi, elektronik ortamların oluşması ulus devletleri klasik kamu yönetimi anlayışından çıkartırken katı hiyerarşik düzeni yıkmış, bürokratik engelleri de ortadan kaldırmıştır. Ancak 19.yy'ın son çeyreğinde başlayan küreselleşme ve 20.yyda gelişen teknoloji sayesinde devletlerin bürokratik yönelimleri de değişmiştir. Bürokrasinin başlıca sorunlarından olan katı hiyerarşinin artık etkili olmadığı, evrak trafiğinin bürokrasiyi çok hantallaştırdığı ve işleri yürütmede engeller teşkil ettiği görülmüştür. Bu nedenle devletler, vatandaşlarına daha hızlı ve etkili hizmetler sunabilmek için; kullanıcıların (vatandaşların) elektronik ortamda sunulacak kamu hizmetlerine farklı platformlardan güvenilir şekilde ve tek noktadan ulaşabilecekleri, vatandaşlarının ve iş insanlarının ihtiyaçlarına odaklanmış, katılımcı, şeffaf ve hesap verebilir yeni yönetim anlayışına geçmişler bu anlayış çerçevesinde de e-devlet sistemleri kurmuşlardır (Metin, 2012, s.99). Özellikle bilgi stratejileri kapsamında vatandaşları yönetime her an dahil edebilme yapısı ile edevlet etkin ve etkili bir kamu yönetimine ulaşma konusunda önemli bir araç olmuştur (DPT, 2009, s.60). E-devlet, e-belediye gibi uygulamalar 
halkın, bürokrasiyi kolayca kırabileceği mecralar olduğu için çalışma içinde bürokrasi kelimesi kırtasiyecilik özelinde değerlendirilmiştir.

Bürokrasinin sorunlarının azaltılması için geliştirilen yeni yönetim anlayışının ve küreselleşmenin getirdiği en önemli kavramlardan birisi de yönetişimdir. Genel olarak hizmetlerin ve vatandaşa ulaşmanın; merkezi yönetimlerden, yerel yönetimlere kaydırılması olarak tanımlanmaktadır. Halka en yakın yerel yönetim birimi olan belediyelerin uygulamaları ise halkın daha kolay ulaşarak hizmetlerden yararlanabilmesi ya da şikâyetlerini dile getirebilmeleri açısından önemlidir. Bu nedenle çalışmada e-belediyecilik ön plana çıartılmış bu kapsamda da Ankara Büyükşehir Belediyesinin e-belediye uygulamaları internet siteleri üzerinden araştırılmış, Başkent 153 uygulaması incelenmiş ve bürokrasinin sorunlarına çözüp olup olamadığ irdelenmiştir.

\section{Bürokrasi ve Bürokrasi Kuramları}

Devletlerin bürokrasiyi yarattığı düşünülse de aslında tarihsel gelişimine bakıldığında bürokrasi devletten de önce ortaya çıkmıştır. İsmi o zamanlar bürokrasi olmasa da devlet yokken toplum adına yapılması gereken iş ve faaliyetlerin bir düzen içinde yerine getirilmesi için kurulan otoriteler aslında bürokrasiyi oluşturmaktadır (Akçakaya, 2016, s.275). Buna göre aslında bürokrasinin devleti oluşturduğu bile düşünülebilir. Bürokrasi bu anlamda, bir toplumda, tabandan yukarıya çıktıkça daralan bir yapı içinde örgütlenmiş olan, kişisel olmayan işleyiş ve kurallar olarak tanımlanabilir. Kelime kökeni devlet için işlerin yürüdügü "büreau" ile hakimiyet ve iktidar anlamındaki "cratie" kelimelerinin birleşmesiyle oluşmuştur ve en genel tanımıyla devlet dairlerinin hakimiyetini ifade etmektedir (Dursun, 1992, s.133). Bürokrasinin devlet kademelerinde ve halk arasında kullanımı oldukça farklıdır. Genel olarak siyaset biliminde devlet yönetimini, devletin örgütlenişini ve personelini ifade ederken, işletme biliminde belirli bir örgütlenme ve yönetim biçimi olarak ifade edilmekte, halk arasında ise bunlardan tamamen bağımsız olarak kırtasiyecilik, işlerin yavaş yürümesi ve hantal devlet anlayışını ifade etmektedir (Dursun, 1992, s.133). Bürokrasinin tanımları gibi kuramları da çeşitlilik 
göstermektedir. Bürokrasi literatürüne kuramsal olarak katkıda bulunan düşünürler olarak ise Weber, Marx, Hegel ve birçok düşünürün bir arada bulunduğu Seçkinci Bürokrasi Kuramı karşımıza çıkmaktadır.

Bürokrasi, denince akla ilk gelen isim olan Weber'e göre bürokrasi, kırtasiyecilikten ziyade bir örgütlenme ve yönetim biçimdir. Ona göre bir arada çalışan insanlar belirli bir büyüklüğe ulaştıktan sonra rasyonel ilkelere uygun olarak örgütlenerek yönetmekte ve yönetilmektedir (Şahin, 1998, s.48). Weber'e göre de diğer düşünürlere göre de bürokrasi sanayileşmenin sonuçlarından birisidir. $\mathrm{Bu}$ nedenle Weber modern bürokrasinin ortaya çıkışını kapitalizme bağlamaktadır (Akçakaya, 2016, s.675). Weber, kendi bürokrasisini ideal tip olarak tanımlarken, uygulanan bürokrasiden bahsetmemekte ütopyası olan bürokrasiden bahsetmektedir. Uygulanan bürokrasi tipi ile ideal tipi kıyaslayarak uygulanan bürokrasideki eksikleri tespit etmeye çalı̧maktadır. Yani aslında ideal tip bürokrasi mevcut bürokrasinin kıyaslanabileceği bir ölçüt, bir kontrol noktasıdır (Akçakaya, 2016a, s.677). Weber'in kurduğu ideal tip bürokraside önemli unsurlardan birisi de herkesin yeteneğine ve bilgisine göre görev yapmasını ifade eden liyakattır. Bu durumda bürokrasinin aslında üç kesimin konusu olduğu ortaya çıkmaktadır. Birinci kesim siyasetçiler, ikinci kesim halk ve üçüncü kesim memurlardır. Liyakat bürokrasi çarkının, memurlar dişlisinde önem taşımaktadır. Memurların liyakat göz önünde olmadan dirsek teması ile görevlere getirilmeleri bürokrasinin iyi işlemesinin önündeki engellerden de bir tanesidir (Aydın, 2012, s.52). Hegel'e göre ise bürokrasi, halkın isteklerini devletin karşılaması için oluşturulmuş bir örgüttür ve böylece halk ile devlet arasındaki bir köprü görevi görmektedir (Aksan ve Çelik, 2011, s.3).

Marks ise Weber'den ve Hegel'den bağımsız olarak ve onların tersi düşüncede geliştirdiği kuramında bürokrasiyi kapitalizmle ilişkilendirmektedir. Ancak bunun yanı sıra bürokrasi halktan bağımsız, ayrıcalıklı bir sınıfın çıkarlarına hizmet eden (sermayeyi elinde tutanlar), üretimi gerçekleştiren emekçilerin denetiminden de uzak bir yönetim sistemidir. Bu açıdan bürokrasinin özünde aslında sınıf ilişkileri vardır. Marx, Hegel'in devletin halkın çıkarlarını düşünmek için oluşturulan bürokrasi kavramının tamamen karşısındadır. Çünkü ona göre devlet toplumun değil, sermayeyi elinde tutan sınıfın çıarlarını korumaktadır. 
(Aydilek, 2019, s.61). Doğal olarak da bürokrasi, aslında sadece sermayeye hizmet etmektedir. Bu durumda tek amaç da aslında sermayeye hizmet eden statükoyu korumaktır. Bu döngü sermaye egemenleri ile devlet bürokrasisi arasında sürekli bir döngü içerisinde karşılıklı çıkara dayalı olarak devam etmektedir.

Seçkinci bürokrasi kuramı ise toplumun yöneten ve yönetilen sınıf olarak ayrılması ve yöneten sınıfın bürokrasiyi oluşturması şeklinde ifade edilebilmektedir. Kendi içerisinde dalları olan seçkinci bürokrasi kavramının akla gelen ilk ismi olan Alman sosyolog Robert Michels bürokrasiyi modern toplumların oligarşik eğilimlerine bağlamıştır (Akçakaya, 2016a, s.681). Oligarşinin Tunç Kanunu olarak adlandırılan bu kurama göre, örgütteki kişi sayısı artınca aralarındaki iletişim yüzünden örgütlenmeler başlayacak ve bu gruplar arasındaki iletişim bürokrasiyi oluşturacaktır. En güçlü grup, yönetimde en çok söz sahibi olan grup olacağ 1 için de bürokrasiyi belirleyen grup olacaktır. Michels'e göre seçkin olan bu grup seçkinci bürokrasiyi oluşturmakta ve doğal olarak da bürokrasiyi istedikleri gibi kullanabilmektedir. Doğal olarak da bürokrasi sadece seçkin grubun çıkarına hizmet eden bir örgüt olacaktır. Michels Oligarşinin Tunç Kanunundan bahsederken demokrasi vaat eden ancak kendi içlerinde demokratik olmayan Alman Sosyal Demokrat partiyi ele almıştır. Sadece demokrasi vaat etmeyen muhafazakâr partileri ise çalışması dişında tutmuştur. Onun haricinde diğer partilerin hepsinin bürokrasi derken aslında oligarşiden bahsettiklerini belirtmiştir (Erdoğan, 2018, s.65). Seçkinci bürokrasi kuramında marksist olan Rizzi, bürokratik kolektivizmden bahseder. Her Marksist gibi o da bürokratların üretim araçlarını ellerinde tuttukları için hâkim gücü teşkil ettiklerini söyler. Kapitalist sistemle bu sistem arasındaki en belirgin fark tasarrufun bireysel değil toplumsal oluşudur (Akçakaya, 2016a, s.681). Mosca ise "yönetici sınıf teorisi" ile seçkinci bürokrasi kuramına katkıda bulunmuştur. Ona göre toplum yöneten sinıf ve yönetilen sinıf olmak üzere iki tabakadan meydana gelmektedir. Yönetici sınıf üretim araçlarını elinde bulunduran ve genellikle de iktidarın nimetlerinden yararlanan sinıftır. Zaten iktidar da kendileridir. Sayıca az ama bürokratik güç olarak fazlalardır. Yönetilen sınıf ise, yönetici sınıfın isteklerini karşılayan, emeğini ortaya koyan ama 
emeğinin karşılığını tamamen göremeyen sınıftır. Sayıca çok olmalarına rağmen bürokratik güçleri yoktur. (Arslan, 2008, s.118).

Genel olarak sermaye gücünü elinde bulunduranların bürokratik teşkilatlanmayı oluşturdukları ve bir süre sonra devletin nimetlerinden en çok bürokratik kesimin yararlandığını ifade eden kuramlara göre bürokrasi devletin işleyişi anlamında gerekli olsa da birçok sorunu da beraberinde getirmektedir. Bürokrasiyi oluşturan kesim kendi işlerini halledebilme yetisine sahip olduğu ve zaten sorunları bizzat kendisi yarattığı için bürokratik sorunları görmezden gelirken, devlet işleyişindeki sıkıntılar yüzünden en büyük sorunu yönetilen sınıf yani halk yaşamaktadır. Halkın gözünden bürokrasinin sorunlarını tespit etmek, sorunları çözmek ve demokratik bir eşitlik yaratmak önemlidir.

\section{Türk Kamu Bürokrasinin Sorunları}

Her bürokratik örgütün sorunları olduğu gibi Türk kamu bürokrasinin de kendine ait sorunları vardır. Ancak bu sorunlar içinde bulunduğumuz zamandan, siyasi koşullardan, teknolojik gelişmelerden, ekonomik ve sosyal ortamdan ve kültürden bağımsız düşünülemez. Bu nedenle bu sorunlara çözüm ararken belirtilen tüm faktörler çözüm önerisine dahil edilmeye çalışılmalıdır. Bürokrasi, devlet yönetiminin örgütlenmesi olarak tanımlandığında bürokratik sorunlar da yapısal ve davranışsal sorunlar olarak iki ayrı grupta ele alınmaktadır (Eryılmaz, 2015, s.260).

Türkiye'de, Osmanlı devlet yönetiminin Tanzimat döneminden beri en önemli yapısal sorunu olan yönetimde merkeziyetçilik devam etmiştir (Gökçe ve Şahin, 2002, s.11). Bu nedenle de yapısal sorunların başında merkeziyetçilik gelmektedir. Merkeziyetçilik ise hem genel hem de özel olarak ele alınabilecek bir sorundur. Tek bir noktadan yönetimi ifade eden merkezi yönetimin genelleştirilebilecek sorunu, merkez teşkilatın, taşra teşkilatına ve yerel yönetim kuruluşlarına görev vermesi ancak o kuruluşların verilen görevi yerine getirmesini gerektirecek yetkiyle donatılmamaları sonucu ortaya çıkmaktadır. Özelleştirilebilecek sorun ise bir örgüt içerisindeki karar alma ve uygulama yetkilerinin örgütün en üstünde bulunan kişi ya da kişilerde toplanmasını ifade eden örgütsel merkeziyetçiliktir. Yasalar da özellikle yerel yönetimlerin, merkezi 
yönetime karşı elini güçlendirebilmek için yetki genişliği ve yetki devri gibi kavramlar olsa da siyasi konjonktür buna izin vermemekte yerel yönetimler, merkezi yönetime danışmadan ya da merkezi yönetimin çıkarlarına aykırı hareket edememektedir. Bu durum da kırtasiyeciliği arttırmakla birlikte kararların ve halka ulaşması gereken hizmetlerin gecikmesine sebebiyet vermektedir (Selçuk, 2010, s.37).

Bürokrasinin yapısal diğer sorunu ise örgütsel büyümedir. Nüfusun artışına ya da krizlere bağlı olarak devletin büyümesi bir zorunluluk olarak kabul edilirken örgütsel büyümenin bürokratik bir sorun olduğu nokta "yapay" bir büyümenin olmasıdır (Aktan, 2011, s.33). Kamu yönetimi halka hizmet için hizmet kalitesini arttırmak yerine kaliteyi arttırabileceğini düşünerek genellikle bütçe, personel, araç, ofis vb. sayısını arttırma yoluna gitmekte bu da örgütü varlıklar açısından büyütürken, işlevsel açıdan büyütmemektedir ve gereksiz yere büyüyen örgüt ise bürokratik aşamaları arttırmaktadır (Eryılmaz, 2015, s.301).

Yönetimde gizlilik ve dışa kapalılık ise diğer bir sorundur. Ülkemizde bürokrasi, geleneksel olarak gizlilik ve dışa kapalılık unsurlarını barındırmaktadır. Gizlilik ve kapalılık aynı anlamda kullanılsalar da aslında birbirinden farklı kavramlardır. Gizlilik; kamu yönetimindeki bilgilerin, belgelerin ve verilerin paylaşılmaması olarak tanımlanırken kapalılık ise kamu kurumlarının dışarıdan gelecek etkilere karşı kendilerini kapatmaları, duyarsız olmaları ve eylemlerinin gerekçelerinin bilinmemesi olarak tanımlanmaktadır (Koçak, 2010, s.117). Yönetimde gizlilik ve dışa kapalılık yönetilenlerin yöneticileri ve yönetimi denetleyememe sorununu meydana getirmekte, kapalı kapılar arkasında yasal olmayan birçok durumun yaşanabileceğini düşündürtmektedir (Kırışık, 2013, s.287).

Yönetimde tutuculuk ve değişime ayak uyduramamak ise klasik kamu yönetimi anlayışının bürokrasisinin sorunlarından birisidir. Yöneticiler ve memurlar klasik kamu yönetimi anlayışını devam ettirerek alışkın oldukları ve onları koruyan işleyişi devam ettirme eğilimindedirler. Bu nedenle de bürokrasi güçlenmekte ve sorunlara çözüm ise gecikmektedir.

Bürokrasinin işlevsel sorunları ise literatürde kuralcılık ve sorumluluktan kaçma, siyasallaşma, aracılar yoluyla işleri yürütme ve yolsuzluk olarak ifade edilmiştir. Kuralcılık ve sorumluluktan kaçma ile 
yönetsel örgütlerin tüm işlemlerini önceden belirlenmiş yazılı kurallara uygun bir şekil çerçevesinde yapmalarını böylece örgütün amaçlarının zamanında ve tam olarak yapılması sağlanmaya çalışılmaktadır (Yılmaz ve Kılavuz, 2002, 18). Kuralcılık yöneticilerin ve kamu personelinin sorumluluklarını kurallara atmalarına sebep olmaktayken aynı zamanda da işlerini sadece kuralları uygulamaya indirgemelerine ve böylece denetimden kurtulmalarına zemin hazırlamaktadır (Çevikbaş, 2006, s.276).

Yönetimde siyasallaşma ise bürokratik sorunların başında gelen bir diğer problemdir. Bir kamu görevlisinin işe alımında, terfi ettirilmesinde, rotasyonunda siyasi faktörlere göre hareket edilmesi olarak tanımlanabilecek olan siyasallaşmadaki temel amaç; siyasal iktidarın politikaların etkin ve verimli şekilde uygulamak olsa da her iktidar değişiminde yeni bir kadrolaşmaya gidileceği için bürokrasideki tutarlılığı ve düzeni bozmakta, yönetimin tarafsızlığını olumsuz etkilemektedir. Bu durum, yönetimin yozlaşmasına sebep olmaktadır (Çevikbaş, 2006, s.277).

Bürokraside aracılar yoluyla işleri yürütme de çok sık karşılaşılan hem ahlaki hem de bürokratik bir sorundur. Çünkü vatandaşlar genellikle işlemlerin nasıl olduğu ve sürecin nasıl işlediğini bilmedikleri için bazen kurum bazen de kişi olan aracılar yoluyla işlerini yürütmektedirler (Eryılmaz, 2015, s.307). Ancak aracılar yoluyla işleri yürütmeye çalışmak fırsat eşitliğine de zarar vermektedir.

İşleri yürütebilmek için rüşvet gibi maddi kazançların yanı sıra kayırmacılık gibi maddi değeri olmayan ancak etik açıdan sorunları bulunan yolsuzluk ve rüşvet durumu da bürokrasinin geleneksel sorunlarındandır. Rüşvet yoluyla birçok bürokratik engel aşılmakta ve işlemlerin kısa sürede yapılması sağlanmaktadır (Çakır, 2014, s.21). Küreselleşme ve bilgi teknolojilerinin gelişmesiyle bürokrasinin sorunlarının aşılabilmesi için yeni yönetim yaklaşımları geliştirilmiştir. Hız kazandıran ve bürokratik engelleri azaltması beklenen elektronik devlet (e-devlet) ve elektronik belediye (e-belediye) gibi oluşumlar önem kazanmıştır. 


\section{Değişen Kamu Yönetiminde E-Devlet ve E-Belediye}

Küreselleşme ve liberalleşmenin etkisiyle artık eski bürokratik devlet anlayışının sorunları çözmede yetersiz olduğu görülmüş ve bu nedenle de yeni yaklaşımlar ortaya atılmıştır. Devletin özel bir şirket gibi işletilmesi anlayışı olan yeni kamu yönetimi anlayışı ve onun zemin hazırladığı e-devlet ve e-belediye uygulamaları ile devletler birer şirket, vatandaşlar ise birer müşteri olarak görülmeye ve hizmetler de bu yeni duruma göre belirlenmeye başlamıştır. E-devlet ve e-belediye uygulamaları halkın yönetime katılması, bürokratik sorunların çözüme kavuşması ve devletin katı hiyerarşik yapısının çözülmesinde önemli görülmektedir.

\section{Yeni Kamu Yönetimi Anlayışı}

Klasik kamu yönetimi anlayışının bürokratik etkilerini kırmak ve onun sorunlarına çözüm olabilmek için yeni kamu yönetimi (YKY) anlayışı ortaya çıkmıştır. Özellikle küreselleşmenin etkisiyle dünyanın küçük bir köy olduğu görüşü, herkesin yönetime katılması isteği merkeziyetçiliği esnetmiştir. Bu nedenle 1980'li ve 1990'l y yllar teknolojinin de gelişmesiyle birçok gelişmiş ülkede YKY anlayışı yeni bir model olarak klasik kamu yönetiminin tüm sinırlllıklarının, gelenekselliğinin, katı kurallarının dönüşmesine olanak tanımıştır (Özer, 2005, s.4). Buna göre vatandaşı müşteri olarak gördügü için yönetime daha etkin katılmasını sağlayarak kaliteli hizmet sunma anlayışı güden YKY anlayışı, devletin, özel sektör gibi hareket etmesine neden olmuştur (Lamba, 2014, 137).

Geleneksel Türk kamu yönetiminin YKY anlayışına evrilmesinde ise 1980'lerde başlayan liberalleşme, 1990'lardaki küreselleşmenin yadsınamaz etkisi ile $\mathrm{AB}^{\prime}$ ye uyum süreci için yapılan yönetsel reformlar ve teknolojik gelişmeler etkili olmuştur (Ökmen ve Canan, 2009, s. 139140). Bu reformlar YKY anlayışının da benimsenmesi olarak algılanmaktadır. YKY anlayışında özel sektöre özgü işletme kavram ve tekniklerinin kamuya uyarlanması söz konusudur. YKY'de klasik kamu yönetimi anlayışı yerine piyasanın durumunu ve vatandaşın (müşterilerin) memnuniyetini ön plana koyan, esnek, bürokratik 
tabakaları daha az, sonuç odaklı ve girişimciliğe önem verildiği vurgulanmaktadır (Özer, 2005, s.11).

Yeni yönetim anlayışında, geleneksel yönetimin merkeziyetçi yapısı yerine yerel yönetimlere önem verilmiş, gizlilik ve dışa kapalılık ilkesi yerine açıklık ve şeffaflık ilkeleri ön plana çıkartılmış, etkinlik ve verimliliğin önemi arttırılmış, halkı yönetime dâhil edebilmek için yönetişim kavramı vurgulanmış ve yönetimin hesap verebilir olması amaçlanarak vatandaş (müşteri) odaklı, halka yakın ve yerinden bir yönetim sistemi benimsenmeye çalışılmıştır (Sezer, 2008, s.148). Bu yeni yönetim anlayışı " $\mathrm{e}$ " yapılanma e-devlet ve e-belediye gibi uygulamaların zeminini de hazırlamıştır.

\section{E-Devlet}

Küreselleşme ile birlikte devlet küçülmüş, teknolojinin gelişmesiyle de bilinçlenen halk, dönüşen yönetim yapısında devletten daha sonuç odaklı ve kaliteli hizmet talep etmiştir (Göküş, 2010, s.205). Devletler ise halkın ihtiyaçlarına daha hızlı çözüm üretebilmek, aradaki bürokratik engelleri kaldırabilmek için bilişim teknolojilerinin ve internetin gelişmişliğinden faydalanarak elektronik devlet (e-devlet) sistemleri kurmuşlardır. E-devletin yaygınlaşmasındaki temel neden, klasik kamu yönetiminin hantallık, kırtasiyecilik, verimsizlik ve bürokrasi gibi sorunlarının vatandaşın gözünde yarattığ1 ciddi meşruiyet krizini çözmektir (Delibaş ve Akgül, 2010, s.106). E-devlet genel olarak devletin vatandaşlarına karşı yerine getirmesi gereken görev, sorumluluk ve hizmetler ile vatandaşın devletine karşı yerine getirmesi gereken ödevlerin, sorumlulukların ve taleplerin karşılıklılık esasına dayanarak kesintisiz yürütülmesi olarak tanımlanmaktadır (Demirel, 2006, s.84). Başka bir ifade ile e-devlet, devletlerin bütün bürokratik, hukuki ve ekonomik işlemlerini internet ağları üzerinden doğrudan yapabilmesine imkân veren, vatandaşların ve devletin birbirlerine karşı görevlerini güvenle ve hızlıca yürütebildikleri, hizmetlere istediklerinde zaman ve mekân kısıtlaması olmadan ulaşabildikleri elektronik bir yapıdır (Efendioğlu ve Sezgin, 2007, s.220). Türkiye özelinde ise e-devlete geçiş süreci özellikle 1980'lerin ikinci yarısından sonra liberalleşme politikaları ile başlamış, ancak uygulamaların e-devlet olarak adlandırılması 1990'lı 
yıllarda bilgisayar kullanımı ve internet altyapısının geliştirilmesiyle mümkün olabilmiştir. 2000'li yıllarda ise e-devlet uygulamaları AB'ye uyum süreci çerçevesinde geliştirilmiş ve daha ciddi şekilde devlet politikaları ile iç içe geçerek halkın hizmetine sunulmuştur (Çarıkçı, 2010, s.97). E-devlet ile vatandaş- devlet etkileşimi sağlanmaya çalışılmış ve devlet, e-devlet ile halkın sesini duyarak ve halkı yönetime dahil ederek politikalarını belirleyebilmiştir (Demirel, 2006, s.94). E-devlet uygulaması ile amaçlananlar; harcamalarda tasarruf sağlanması, kâğıt işlemlerinin azaltılması ve kontrol altına alınması, "halk için devlet" anlayışı ile şeffaflık, açıklık, hesap verilebilirliğin sağlanması, hizmet kalitesinin arttırılması ve kamu hizmetlerine $7 / 24$ her vatandaşın kolayca erişebilmesinin sağlanması ile halkın yönetime katılmasının arttırılması olarak sıralanabilir (Şahin ve Örselli, 2003, s.348-349). “E” yapılanmaların sorunları ise yeterli bir hukuki ve internet altyapısının olmaması, halkın bilgisayar okur-yazarlığının düşük olması, standardize edilmiş bir sistemin olmaması, gelişmekte olan ülkelerde e-devleti oluşturmak için yeterli finansmanın sağlanamaması, teknolojik altyapıyı ve uygulamanın yazılımını oluşturabilecek düzeyde bilgisayar yazılımcısının olmaması ya da yetişmiş bilgi teknolojileri personeli eksiği olarak ifade edilmektedir (Çakır, 2015, s.9-10).

\section{E-Belediye}

Türkiye'de anayasal düzende merkezden ve yerinden yönetim ilkelerine göre bir yapılanma vardır. Bu nedenle merkezi yönetim ile yerel yönetimlerin elektronik yapılanma çalışmaları birbiriyle bağlantılıdır (Şahin, 2007, s.163). Vatandaşın yönetime katılması noktasında yönetimde, merkezi yönetime paydaş olan yerel yönetimler, sendikalar, özel sektör ve vatandaşların yönetime ortak olduğu yönetişim sistemi benimsenmiştir (Göküş, 2010, s.208). Yönetişimin ise en uygulanabilir olduğu birim yerel yönetimlerdir. Teknolojinin getirdiği hızlı dönüşümün en çok etkilediği kurumların başında vatandaşların kamu hizmetlerine ulaşmada yakınlık açısından ilk adımları olan belediyeler gelmektedir (Erdoğan, 2019, s.556). Bu yakınlık belediyelerin, halkın isteklerini daha kolay belirleyebilmelerine, bütçelerini vatandaşların ve kentin ihtiyaçları doğrultusunda harcayabilmelerine ve sorunlara daha 
hızlı çözüm bulabilmelerine imkân tanımaktadır. E-belediye aracılığı ile belediye-vatandaş arasında iletişim ve hızlı bilgi alışverişi sağlanmaya çalışılmakta kaliteli hizmet sunumunun geliştirilmesi hedeflenmektedir (Hazman, 2005, s.70). E-belediyenin bürokrasinin katılığından kaynaklanan hantallığı aşmasının yanı sıra kaynak israfını önleyerek tasarrufa imkân tanıması da önemlidir (Metin, 2012, s.105). Buna göre bürokrasinin sorunlarından kurtulmak için E-belediyeden beklenen faydalar şöyledir; (Şahin, 2007, s. 167; Acılar, 2012, s.133; Hazman, 2005, s.70).

- Belediye ile vatandaş arasında hızlı ve etkili iletişim kurmak

- Bürokrasinin; hantallık, kırtasiyecilik, gizlilik ve dışa kapalılık, aracılarla iş yapma, zamana ve mekâna bağımlılık, hiyerarşi gibi sorunlarını çözmek

- Belediye ile vatandaş arasında kolay bilgi akışı sağlamak

- Yerel halkın ihtiyaçlarına göre hizmetlerin sunulması, projelerin yapılması ve kaynakların doğru kullanılmasını sağlamak

- Belediye ile vatandaş ilişkilerini güçlendirmek

- Vatandaşa sunulan hizmet kalitesini arttırmak

- Vatandaşların ve yerel halkın yönetim sürecine katılmalarını sağlamak ve dolayısıyla demokratikleşmenin arttırılması

- Karar alınırken halkın isteklerini belirleyebilmek

- Vatandaşın bürokratik engellere takılmadan daha kolay ve hızlı işlem yapabilmesini sağlamak

- Zaman ve kaynak tasarrufu yapabilmek

- Vatandaşlara karşı şeffaf, hesap verebilir bir yönetimin sağlanabilmesi ve böylece yönetimin meşruiyetinin arttırılması

- Zaman ve mekân olgularının kaldırılarak hizmetlere 7 gün 24 saat hizmet verebilmek ve hizmetlere ulaşılmasını sağlamak

- İmar, ihale gibi ekonomik konularda ortaya çıkabilecek yolsuzlukların azaltılmasını sağlayarak vatandaşın yönetime olan güveninin artması

- Tüm vatandaşlara bilgisayar ve internet bağlantısı ulaştırılması sonucunda ortaya çıkan fırsat eşitsizliklerini engellemek olarak belirlenmiştir.

Son dönemde ise 23.07.2019 tarihinde Resmi Gazete'de yayımlanan 2019-2023 yıllarını kapsayan 11. Kalkınma Planı'nda yer alan Türkiye'de 
İçişleri Bakanlığı'nın öncülüğünde e-belediye bilgi sistemi uygulaması geliştirilmiş ve tüm belediyeler tek veri tabanında ve ortak altyapıda tüm iş ve işlemlerini yürütebilir duruma gelmişlerdir. E-belediye bilgi sistemi, belediyeler ve kamu kuruluşları arasındaki farklı uygulamaları standartlaştırmak, koordinasyonu arttırmak ve sorunları azaltmak için kurulmuştur (Erdoğan, 2019, s.564). Tamamen ücretsiz olan bu uygulama ile belediyelerin yaptığı, iş yeri açma ruhsatı verme gibi işlemler elektronik ortamda yapılacaktır ve bu sistem sayesinde belediyelerin yıllık 2 milyar lira kaynak tasarrufu sağlayacakları öngörülmektedir (www.belediye.gov.tr, 2020). Uygulamanın bürokrasi kırıcı etkisi ise geliştirilen yönetici modülünün yönetim destek mekanizmasına katkılarındadır. Bu modüle göre karar mekanizması güçlendirilecek, belediye yönetiminde kolaylıklar sağlanacak, belediyenin hizmetleri, yapılan işler ve işlemleri belediye başkanına ya da ilgili birimin yöneticisine anında raporlanabilecektir (www.belediye.gov.tr, 2020). E-devletle de entegre olan yap1 vatandaşların belediye ile ilgili yapacakları tüm işlemleri içermekte ve böylece vatandaşların zaman kaybetmeden hizmetlere kolayca ulaşmasını sağlamayı hedeflemektedir. İçişleri Bakanlığı personeli tarafından ayrıca bir kaynak harcanmadan geliştirilen uygulamanın açık kaynak kodlu olması ve milli işletim sistemi PARDUS ile çalışacak şekilde tasarlanması dışa bağımlılığı azaltmakta ve kişisel verilerin korunması kanunu uyarınca bilgilerin başka ülkelerin eline geçmemesi konusunda da önemli bulunmaktadır. E-belediye uygulamasında sadece İçişleri Bakanlığı'nın değil, Çevre ve Şehircilik Bakanlığının da modüllerinin bulunması sonucu belediyeler ile bakanlıkların iş birliklerinin arttırması hedeflenmektedir. E-belediye uygulaması ile belirlenen son hedef ise 2020 yılının sonuna kadar tüm belediyelerin sisteme entegre olmasidır (www.belediye.gov.tr, 2020). E-belediye sisteminde vatandaşlara sunulan hızlı hizmetler; elektronik evrak doğrulama, elektronik evrak takibi, istek şikâyet talebi ve sorgulama, sosyal yardım talebi ve sorgulama, e-dilekçe kayıt, iş yeri açma ruhsatı başvurusu ve iş yeri açma ruhsatı başvuru sorgulama (https://www.belediye.gov.tr/, 2020) olarak görülmektedir. Vatandaşlar bu uygulamalar sayesinde özellikle iş yeri açma ruhsatı gibi zaman alan 
ve birçok bürokratik engeli olan işlemleri kolayca gerçekleştirebilmektedirler.

Tüm belediyelerin sisteme entegrasyonu ise belediyeleri kendi web sitelerinde hangi hizmetleri vermeye yöneltecek, kendi web sitelerindeki hizmet sunumunda bir değişiklik olacak mı? işlemler tüm belediyelerin tek çatı altında toplandığı e-belediye uygulaması ile yapıldığında her belediyenin ayrı bir web sitesinin olmasına gerek kalmayacak mı? sorularını bünyesinde barındırmaktadır. Ancak kamunun " $\mathrm{e}$ " uygulamalara yönelmesi, bu uygulamaların kullanılabilirliği açısından değerlidir. Bu noktada vatandaşların da bilgisayar ve internet okuryazarlığının arttırılarak uygulamaları aktif olarak kullanmalarının sağlanması uygulamaların asıl amacına ulaşmasında en önemli faktörlerden birisidir (Önal ve Alaca, 2017, s.117).

\section{Ankara Büyükşehir Belediyesinin Web Sitesinin E-Belediye Uygulamaları Açısından İncelenmesi}

Bugün Türkiye'de birçok belediyede olduğu gibi Ankara Büyükşehir Belediyesi de teknolojinin ve internet altyapısının gelişmesinden yararlanmakta hizmetlerinin birçoğunu internet sitesi ve e-belediye uygulamaları üzerinden vermektedir. E-belediye uygulamaları sadece ödemelerin ve tahsilatların online olarak yapılacağı bir mecra değil aynı zamanda şeffaf, hesap verebilir, vatandaş odaklılığı sağlayan, halkı yönetime dahil eden, belediye hizmetlerine 7/24 ulaşım sağlayarak hiyerarşiyi ve bürokratik sorunları kıran bir mecra olarak düşünülmektedir. Bu çerçevede çalışmada Ankara Büyükşehir Belediyesinin internet ana sayfasındaki hizmetleri, Başkent 153 hizmetleri bürokrasinin sorunlarını çözüp çözmediği bağlamında ve yeni yönetim yaklaşımının ilkeleri çerçevesinde incelenmiştir.

\section{Web Sitesi Ana Sayfa İncelemesi}

Ankara Büyükşehir Belediyesi e-belediyeyi etkin ve hızlı bir iletişim aracı olarak kullanan belediyelerden bir tanesidir. Web sitesinde belediyenin kurumsal teşkilatını, sosyal ve kültürel hizmetlerini, gösteren ayrıca direkt başkana ulaşabilmenizi sağlayan uzantılar 
bulunmaktadır (https://www.ankara.bel.tr/, 2020). Başkana mesaj kısminda ad, soyad, cep telefonu ya da ev telefonu, mail adresi, kimlik numarası ve ilçe seçildikten sonra başvuru metni yazılabilecek bir bölüm bulunmaktadır. Buradan belediye başkanına doğrudan ulaşılabilir ve sorunlar ya da belediyeden beklentiler iletilebilir. Web sitesinin içindeki bu uzantı belediye içindeki bütün bürokratik ve hiyerarşik engelleri kaldırarak belediye başkanına vatandaşların doğrudan ulaşabilmelerini sağladığı için oldukça olumludur (https://www.ankara.bel.tr/baskan/baskana-mesaj, 2020). Ayrıca kişisel verilerin korunması sebebiyle cep telefonuna gelen kisa mesajla doğrulama yapılması istenmektedir.

Belediyenin ana sayfasındaki sosyal hizmetler alanı da hem sosyal belediyecilik anlayışı gereği hem de vatandaş odaklılık anlayışı çerçevesinde değerli ve sosyal hizmetlere başvurunun kolayca yapılmasını sağlayarak bürokratik engelleri aştığı, kırtasiyeciliği azalttığı, halkı bilgilendirerek yönetime dahil edebilmenin yolunu açtığ1 için önemlidir. Sosyal hizmetler butonun altındaki kadın danışma birimi, sığınma evi, çocuk ve gençlik hizmetleri ise toplumun dezavantajlı kesimlerine etkili, hızlı ve bürokrasiye takılmadan doğrudan hizmet verebilmenin yolunu açmaktadır (https://www.ankara.bel.tr/sosyalhizmetler, 2020).

Belediyenin web ana sayfasındaki kültürel hizmetler alanında ise BELMEK, BELTEK gibi meslek edindirme ve geliştirme kurslarının yanı sıra FOMGED halk oyunları kursu ve kent orkestrası ve konserlerin ne zaman yapılacağı ile ilgili bilgiler bulunmaktadır. Ancak BELMEK, BELTEK ve FOMGED gibi kurslara katılım için belirtilen alanda herhangi bir kayıt butonu bulunmaması belediyenin bir eksiği olarak değerlendirilebilir. Kurslara katılım başvuruları şahsen yapılmaktadır. Bürokrasinin sorunlarından olan hiyerarşinin, zaman ve kâğıt israfının azaltılması amacıyla belediyenin bu tarz kurslarına başvurularının, belediye web sayfası üzerinden ya da e-belediye uygulamaları ile alınmasının bürokrasiyi ve hiyerarşiyi azaltmasında önemli olacağ1 düşünülmektedir (https://www.ankara.bel.tr/kulturel-hizmetler, 2020).

Yeni yönetim anlayışının getirdiği şeffaflık ve hesap verebilirlik noktasında Ankara Büyükşehir Belediyesi'nin ana sayfasında bulunan saydamlık ve hesap verilebilirlik butonu ile halk bilgilendirilmeye 
çalışılmaktadır. Saydamlık ve hesap verebilirlik butonu altında belediyenin meclis faaliyetlerine, stratejik yönetim araçlarına, denetim, ihale ve satın alma, sosyal yardım ve hizmet raporları ile mali rapor ve tablolarına ulaşılabilmektedir. Bu bilgilerin halk ile paylaşılması belediyenin şeffaflı̆̆ını arttırırken ayrıca halk denetiminin yolunu açarak işlemlerin hesap verilebilir olmasını da sağlamaktadır (https://www.ankara.bel.tr/saydamlik-ve-hesapverilebilirlik, 2020).

Halkın haberdar olabilmesi için yine ana sayfada bulunan ihale duyuruları ile tamamlanmış ihaleler, konut ve ticari satış ihaleleri, taşınmaz mal ihalelerine ulaşılabilmektedir. Şeffaf belediyecilik için kapalı kapılar ardında kimsenin haberi olmadan ihaleye çıkılmaması önemlidir. Ankara Büyükşehir Belediyesi web sitesinde bulunan e-ihale uzantısı ile şeffaf yönetim gereği ihaleleri sosyal medya hesapları üzerinden ve Youtube aracılığı ile canlı olarak yayınlamaktadır (haber3, 2019). Böylece bürokrasinin gizlilik ve dışa kapalılık sorununa bir çözüm yolu getirilmiş olmaktadır. Ancak ihaleye çıkan isteklere teklif vermek internet sitesi üzerinden mümkün değildir. Sitede bir ihaleye katılmak için gerekli bilgiler verilmiştir. Açılan bir ihale için belirlenen prosedürlere bakıldığında ihalelere teklif vermek elden ya da iadeli taahhütlü posta aracılığı ile yapılabilmektedir. $\mathrm{Bu}$ da aslında bürokrasinin hantallı̆̆ı ve kırtasiyeciliği sorunlarını doğurmaktadır (https://www.ankara.bel.tr/ihale-duyurulari, 2020). Oysaki teklifler ebelediye üzerinden gerçekleştirilse zaman kaybı olmayacak ve kırtasiyecilik azalacaktır. Bunun yanı sıra "belediye bugün ne yapıyor?" başlı̆̆ 1 altında belediye hizmetlerinin hangi lokasyonda ve hangi hizmetin verildiği halk tarafından incelenebilmektedir. Bu durum halk tarafından denetlenebilirliğin önünü açmaktadır. Örneğin, 23.05.2020 tarihi itibariyle Ankara'nın birçok yerinde yol yapım ve asfalt serim çalışması yapıldığı ve yolların kullanıma kapalı olduğu belirtilmiştir. $\mathrm{O}$ güzergâhı kullanacak olan vatandaşlar, belediyenin internet sitesine baktıklarında trafikte zaman kaybetmeyeceklerdir (https://www.ankara.bel.tr/buyuksehir-bugun-ne-yapiyor, 2020). Ayn1 şekilde belediye etkinlik takvimiyle de vatandaşlara hangi etkinliklerin saat kaçta ve nerde olduğu bilgisi verilmekte; böylece vatandaşların haberdar edilmesini kolay yoldan, broşür ve afiş bastırmadan, reklam vermek gibi ekstra maliyetler olmadan hatta somut çöp bile oluşmadan 
sağlayabilmektedir (https://www.ankara.bel.tr/etkinlik-takvimi). Bu durum, belediyenin kaynaklarını tasarruflu kullanması açısından önemlidir. Yine ana sayfada bulunan ve büyükşehirlerde yaşanan trafik ve otobüs bekleme sorunlarını asgari düzeye indirmeye çalışan ve otobüs güzergâhlarını göstererek vatandaşın bilmediği bir noktaya hangi otobüs ile gidebileceğini öğrenme imkânı sunan EGO haritası vatandaşa sunduğu hizmet açısından önemlidir (http://map.ego.gov.tr:8080/ego/index.aspx, 2020). Özellikle pandemi sürecinde insanların otobüs duraklarında yoğunluk oluşturmamalarının bu uygulama ile sağlanabileceği düşünülmektedir. Mezarlıklarla ilgili de defin işlemleri ve mezar yeri bulma konusunda bilgilere belediyenin internet sayfası üzerindeki Mezarlık Bilgi Sistemi aracılığı ile kolayca ulaşılabilmektedir (https://mebis.ankara.bel.tr/, 2020). Ayrıca e-tahsilat ile vatandaşlar sicil numaraları ya da kimlik numaralarıla belediyeye olan ödemelerini evlerinden istedikleri saatte kolayca yapabilmektedirler (https://tahsilat.ankara.bel.tr/OnlineTahsilat/sicilsorgu.htm, 2020). Aynı durum belediye şirketleri için de geçerlidir. Örneğin Ankara Su ve Kanalizasyon İdaresi (ASKİ)'ne su faturası borcu olan vatandaşlar uygulama aracılığı ile faturaları ile ilgili bilgilere ulaşıp (geçmiş dönem faturası, güncel fatura vb.) ödemelerini online yapabilmekte, evlerinden abonelik başvuru gerçekleştirebilmektedirler (https://onlineislem.aski.gov.tr/, 2020). Pandemi boyunca vatandaşların en sık kullandığı ebelediye uygulamalarından online fatura ödeme uygulamaları olduğu düşünülmektedir. Bu nedenle ASKİ'nin Nisan 2019 ile Mayıs 2021 tarihleri arasında online ödenen fatura sayısı incelenmiştir. İnceleme sonucunda özellikle 2020 Mayıs ayında ödenen online fatura sayısı 180.401 ile dikkat çekmektedir. Bu faturaların su ver kampanyası ile bağlantısının olup olmadığı ise bilinmemektedir. Ancak ilerleyen zamanlarda ise online fatura ödemelerinin bir miktar azaldığı görülse de genelde arttığ1 sonucuna ulaşılmıştır. Özellikle 29 Nisan 2021'de başlayan 17 günlük tam kapanma ile birlikte Nisan 2021'de 63.426 adet online fatura ödemesinin gerçekleştirilmiş olması önemlidir (ASKİ Genel Müdürlüğü, 2021). Buna ek olarak vatandaşların online fatura ödeme bilincinin sadece mücbir sebepler olduğunda değil, olağan zamanlarda da arttırılması gerekmektedir. 
Covid-19 pandemisi ile birlikte merkezi yönetimler kadar yerel yönetimlere de görevler düşmüştür. İnsanların işten çıkartılmaları, salgının kontrol altına alınabilmesi için kafe gibi iş yerlerinin kapatılması pandeminin ekonomiye verdiği zararlardır. Pandemi de yaşanan sorunlara ve sıkıntılara merkezden ziyade yerelde çözüm bulmak daha kolay, hızlı ve etkili olmuştur. Bu nedenle özellikle ekonomik olarak zorluk yaşayan Ankaralılar için Başkan Yavaş, \#AnkaraTekYürek kampanyasını başlatmıştır. Belediyenin ana sayfasında yer alan bu uygulamayla belediye, hayırseverler ile ihtiyaç sahipleri arasında köprü kurma görevini üstlenmiştir (https://ankaratekyurek.com/). Önce su faturalarının ödenmesi ile başlayan ve çok talep gören uygulamaya yeni uygulamalar yüklenmiştir. Seçenekler; su ver, bilet ver, el ver, iftar ver ve afiyet ver olarak kategorize edilmiştir. Su ver kampanyası paydaşı ASKİ'dir. Su ver kampanyası su faturası ödeme ile su abonelik ücreti olarak ayrılmıştır. Çalışma için kontrol edilen zamanda (31.5.2021) tüm su açma bedellerinin ödendiği ancak ödenmesi beklenen 250 adet su faturası borcu olduğu görülmüştür. Buna ek olarak 76,612 adet su faturası ödendiği ve toplam ödenen miktarın 3,597.249 TL olduğu bilgisi yer almaktadır (https://suver.aski.gov.tr/). Bilet ver uygulamasının paydaşı ise EGO (Elektrik Gaz Otobüs)'dur. Bilet ver uygulaması ile hâlihazırda belediyeden yardım alan ve yardım talebinde bulunan ihtiyaç sahiplerinin Ankarakart'larına ödeme yapılabilmektedir. Vatandaşların kendi kartlarına da online yükleme yapabilmeleri için buton bulunmaktadır. Toplam yüklenen Ankarakart adedinin 3225 olduğu ve tutarının da 200.330 TL olduğu görülmektedir. Ancak bu yüklemelerin, vatandaşların kendi kartlarına mi yoksa ihtiyaç sahiplerinin kartlarına mı yaptığı bilgisi ayrılmamıştır. Bu belirsizlik bilet ver kampanyasının ihtiyaç sahiplerine ne kadar destek olduğu konusunda soru işareti barındırmaktadır. Vatandaşlara pandemiden dolayı EGO'nun gelirlerinin \%85 oranında azaldığı ve kendi kartlarına yükleme yaparak destek olunabileceği ifade edilmiştir. Bu uygulama Ankara'da, Ankarakart yükleme noktalarının genellikle metro istasyonlarının altıda olduğu göz önünde bulundurulduğunda vatandaşların kartlarına yükleme yapmak için metro istasyonuna gitme zorunluluğunu ortadan kaldırmıştır. Zaman tasarrufu açısından ve yükleme noktalarında yoğunluk oluşmasının engellenmesi açısından 
olumludur. Ayrıca Ankarakart çıkartmak için Kızılay ve Beşevler kart işlem merkezlerinden randevu alınabilmektedir. Özellikle pandemi döneminde merkezlerde yoğunluk olmaması açısından bu işlem olumlu bulunurken, daha gelişmiş teknolojiler kullanılarak kart devrinin kapatılabileceği ya da kart işlem merkezlerine gerek kalmadan vatandaşların internet üzerinden gerekli işlemleri yaparak kartlarını oluşturabileceği düşünülmektedir (https://biletver.ego.gov.tr/). İftar ver, kampanyası ise BELPA iş birliğiyle ramazan ayı boyunca yapılmış ve herkesin bağışına açılmıştır. Yurtiçinden ve dışından yardımlar yapılmıştır. Toplam hayırsever sayısının 28,875 olduğu, satın alınan iftar paketi sayısının 235,692 olduğu ve iftar ver kampanyasında toplam tutarın 5,892,400.00 TL olduğu bilgisine ulaşılmıştır (https://www.iftarver.com/). Afiyet ver uygulaması ise Başkent Market ile koordineli yürütülmüştür. Uygulama içerisinde küçük, orta ve büyük boy yardım paketleri sunulmuştur. Paketler sırasıyla 150 TL, 200TL ve 250TL olarak belirlenmiştir. Yine tüm ülkeden yardım gelmiştir ve hayırsever sayı1s1 16,737; paket sayıs1 42,610; toplam tutar ise 8,331,500 TL olarak açılanmıştır. Ödeme alındıktan sonra faturanın e-fatura olarak yardım eden kişinin mail adresine gönderileceği ve paketlerin ramazan ayında dağıtılacağı bilgisi not düşülmüştür. Bu noktada; zaten ramazan ayı için ayrı bir uygulama varken afiyet ver uygulamasındaki paket dağıtımlarının ramazan ayında olması uygulamanın eleştirilebilecek yönüdür (https://www.afiyetver.com/). Son olarak 100, 200 ve 300 TL olarak sınırlandırılan el ver uygulaması ise üç adımdan oluşmaktadır. Birinci adımda yardım tutarı seçilmekte ve sonrasında sisteme kayıtlı ihtiyaç sahipleri arasından rastgele bir seçim yapılacağı bilgisi verilmektedir. İkinci adımda ise hayırsever kişi kendi kimlik numarasını doğrulamaktadır ve sistemin seçtiği ihtiyaç sahibinin Ad Soyad ve IBAN bilgileri işlem koduyla birlikte hayırsever kişiye sms ile iletilmektedir. Üçüncü adımda ise işlem kodu üç gün içerisinde geçerli olup yapılan yardımın Havale/EFT Bildirim Forumu üzerinden belediyeye bildirilmesi gerekmektedir. Uygulama özellikle pandemi döneminde yerel yönetimlerin üzerine düşen görevleri yapması adına olumlu olsa da ihtiyaç sahibinin bilgilerinin, hayırsever ile paylaşılması sorunlu olabilir. Belediye'nin hayırsever ile ihtiyaç sahibi arasında sadece haberci olması nakit para akışında şeffaflığı sağlamaya yönelik olabilir. Ya da 
iletilmeyen paranın, hayırsevere iade edilmesinin kolay olması için olabilir ancak yine de belediye bir havuz oluşturarak ihtiyaç sahiplerine yardımı veren el ile alan elin birbirini bilmemesini sağlayarak gerçekleştirebilirdi. Bunlara ek olarak kendisine yardım talebi 300 TL'ye ulaşan ihtiyaç sahiplerinin listeden otomatik olarak kaldırılacağı bilgisi verilmiştir (https://ankaratekyurek.com/elver.php).

\section{Başkent 153}

Ankara Büyük Şehir Belediyesinin vatandaşlarla en interaktif olduğu ebelediye hizmeti ise Başkent 153'tür. Önceleri Mavi Masa adıyla bilinen Başkent 153, Ankara Büyükşehir Belediyesi tarafından yeni yönetim anlayışı geleneği vatandaşların istek ve ihtiyaçlarına zamandan ve mekândan bağımsız 7 gün 24 saat sms, telefon, internet, e-posta, faks gibi iletişim yöntemleriyle ulaşarak kesintisiz hizmet verebilmek için 2003 yılında kurulmuş bir hizmet birimidir (https://mavimasa.ankara.bel.tr/, 2020). Başkent 153; internet sitesi aracılığıyla ya da vatandaşların akıllı cep telefonlarına yükleyebilecekleri Başkent Mobil uygulaması ile taleplerini iletebilecekleri bir platformdur. Genellikle şikayetlerin de iletildiği Başkent 153'de online başvuru oluşturulabilmektedir. Belediye ile ilgili herhangi bir talep, görüş ya da şikâyette başvuru için istenen bilgiler kimlik bilgisi, ad, soyad, cep telefonu, e-mail adresi, eğer gerekliyse fotoğraf, başvuru metni, olay adresi, başvuru tipi (istek, şikâyet, görüş ve öneri, ihbar), yaşanılan ilçe ve eğitim durumu bilgileridir (https://mavimasa.ankara.bel.tr/WebBasvuru\#/, 2020). Başvuru tipine yönelik gerekli alanları doldurulduktan sonra başvuru belediyenin ilgili birimine gönderilmekte ve sonuçlanmaktadır. Aynı şekilde cep telefonu uygulamasında da Başkent 153 butonu ve Acil Bildir butonu bulunmaktadır. Bu butonlar da kullanılarak vatandaşlar belediyelerine evlerinden ulaşabilmekte sorunlarını ve isteklerini hiçbir bürokratik engele takılmadan iletebilmektedirler. Yine vatandaşlar isterlerse belediyenin web sitesinden isterlerse de cep telefonu uygulamasından nöbetçi eczane listesine, afet ve hava durumu bilgilerine, otobüs nerede seçeneği ile otobüslerin saatlerine, ilin belirli bölgelerinde belediyenin devam eden çalışmalarına, trafik durumuna, ASKİnin online işlemlerine ve Ankarakart bakiyelerine kolayca 
ulaşabilmektedirler. Başkent 153, hem yeni yönetim anlayışı gereğince vatandaşı, müşteri olarak görerek memnun etme çabasında hem de bürokratik engelleri kırma noktasında önemli bir oluşumdur.

Belediye başkanlarının da e-belediyecilik ve vatandaş odaklı yönetim düşünceleri belediyelerin hizmetlerinde önemlidir. Ankara Büyükşehir Belediye Başkanı Mansur Yavaş'ın, "teknoloji aşkıyla" sloganını taşıyan Başkent 153'ün tanıtım toplantısında e-belediye ve yeni yönetim anlayışı ile ilgili görüşleri, sunulan hizmetleri doğrudan etkileyeceği için önemlidir. Yavaş, Başkent 153 tanıtım toplantısında Ankaralıların yaşam kalitesini arttırarak, tüm vatandaşlar için fırsat eşitliği yaratmak adına teknolojik gelişmelerin önemli olduğunu ve belediye olarak teknolojik gelişmelerin tüm olanaklarından yararlanıp tüm vatandaşları belediye yönetimine dâhil ederek e-demokrasiyi geliştirmek istediklerini vurgulamıştır (AA, 2020). Yavaş'ın, "Mavi Masa uygulamasını mobil hale getirdiğimiz zaman, 30 bin olan personel sayımı 300 bini bulacak. Madem sizlerin parasın kullanıyorsak o zaman siz de yönetime katılın, eksikleri gösterin. Projelerinizi sunun ve bize yol gösterin. Gelin, hep birlikte kenti yönetelim" ifadeleri yönetişim için önemlidir (Memurlar.net, 2019).

Ankara Büyükşehir Belediyesi, Başkent 153 hizmetini sadece elektronik düzeyde bırakmamıştır. Ayrıca mobil ekipler oluşturarak vatandaşın bizzat evine kadar gidip taleplerini ve şikâyetlerini dinleyerek sorunları daha hızlı ve yerinde çözmeye çalışmaktadır (Hürriyet, 2020). Özellikle Ankara'nın ilçe köylerinde yaşayan vatandaşlar kendilerine yıllar sonra mobil hizmet aracılığı ile hizmet geldiğini ve bürokrasiye takılmadan sorunları çözüldüğü için memnun kaldıklarını belirtmişlerdir (haber3, 2020). E-belediyecilik anlayışı gereği olmasa da belediyenin internete erişme imkânı olmayan vatandaşlara doğrudan hizmet götürerek sorunları yerindelik ilkesi gereği yerinde saptaması açısından, fırsat eşitliği yaratma çabasından ve her bir vatandaşı yönetime dahil etmeye çalışmasından dolayı mobil ekip uygulaması önemlidir.

Başkent 153, belediye başkanı Yavaş'a doğrudan ulaşabilme imkânı da tanımakta böylece bürokratik tüm engeller ve hiyerarşi bir anda kırılmaktadır. Yavaş’ın önceki adı mavi masa şimdiki adı Başkent 153 olan uygulama ile ilgili demeçleri arasındaki "Bu masaya günlük 2 bin 500 mesaj geliyor. Ben de arayanlardan en az 50'sine dönüyorum..." 
(Cumhuriyet, 2020) ifadesi e-belediye uygulamalarının bürokratik engellerin ve katı hiyerarşinin kırılmasında önemli bir etkisi olduğunu göstermektedir.

Hizmet kalitesi arttırılan Başkent 153 ile vatandaşların memnuniyet oranının arttığı da gözlemlenmiştir. \%70 olan memnuniyetsizlik oranı \%49'lara kadar gerilemiş halkın büyük çoğunluğu yönetime dâhil oldukları, bürokratik sorunları aşarak belediye hizmetlerinden kolayca faydalanabildikleri için Başkent 153 hizmetlerinden memnun kaldıkların belirtmişlerdir (Milliyet, 2020).

Korona virüs sürecinde hiçbir evin susuz kalmasını istemediklerini belirten Yavaş, toplam su faturası bedellerinin ise salgın bittikten sonra mahsuplaştırılmasına karar vermiş ve su faturasını ödeyemeyecek olan vatandaşların mağdur olmaması için çaba sarf edildiğini belirtmiştir (http://www.ankara.bel.tr, 2020). Ancak salgından sonra başlayan su sayaçlarının okunup faturalandırılması süreci başladıktan sonra birçok vatandaşın yüksek su faturası şikâyeti olmuştur. Belediye bu şikâyetlerin incelenmesi için bir komisyon kurmuş ve vatandaşların Başkent 153'e bildirdikleri yüksek tutar şikâyetlerinin komisyonca incelenerek konuyla ilgili vatandaşlara tek tek dönüş yapılacağı bildirilmiştir (https://www.instagram.com/ankarabbld/,2020). Böylece vatandaşların su faturası bedeli için ASKİye ya da belediyeye bizzat başvurup dilekçe yazmasına gerek kalmadan sorunlarının çözülmesi ile bürokrasinin kırtasiyecilik ve zaman kaybı sorunları ortadan kaldırılmaya çalışılmıştır.

Son olarak sosyal belediyecilik anlayışı gereği de bürokratik engelleri kırmak amacıyla da Başkent 153 uygulamasına şiddet gören kadınların "tek tık" ile korunmakta, bu uygulama ile hem 7/24 belediye görevlilerince ihbarlar takip edilmekte hem de şiddet gördükleri an belediye ekiplerinin kadınların bulundukları konuma ulaşmaları sağlanmaya çalışılmaktadır. Ayrıca yine mor buton uygulaması ile şiddet gören kadınların belediyeden ücretsiz olarak ve hiçbir bürokratik soruna takılmadan psikolojik destek, sosyal yardım ve barınma talep etmelerinin yolu açılmıştır (https://www.ankara.bel.tr, 2020). Başkent mobil uygulamasının içine entegre edilen "Söz Hakkı" ve "Başkent Genç" modülleri, vatandaşların belediyeye ulaşmaları ve yönetişim kavramının gelişmesinde önemlidir. Kent yönetimine katılımcılık 
ilkesinin artması amaciyla "Söz Hakkı" modülünde 7'den 70'e kadar tüm Ankaralılar nerede ikamet ettiği, eğitim durumu, mesleğini yaptığ1 ilçe gibi çeşitli sorularla ilin demografik verilerinin oluşmasına katkı sağlayacaktır.

$\mathrm{Bu}$ sayede kentin hangi noktasına hangi türde hizmetlere daha fazla ihtiyaç duyulduğu tespit edilebilecek, yönetişim anlayışının uygulanması için adım atılmış olacaktır. Kentin geleceğinde söz sahibi olan Z kuşağı için oluşturulan "Başkent Genç" modülünde ise, gençler fikir ve önerilerini, projelerini ister yazılı ister video çekerek belediyeye iletebileceklerdir. Büyükşehir ise, gençlerden gelen istekleri kategorize ederek ilgili daire başkanlıklarına iletecek ve değerlendirecektir. Böylece gençler ile kent arasında daha sıkı bağlar kurulması, gençlerin kent yönetimine katılmaları sağlanmış olurken gençler sayesinde gündemi yakalamak ve yeni hizmet alanları oluşturmak belediyeye katkı sağlayacaktır. Bu modüller ile dünyada örnekleri bulunan Akıllı Kent uygulamaları Başkent'te de hayata geçirilirken yeni dijital uygulamalarla e-demokrasinin temelleri atılmış olacaktır (https://www.ankara.bel.tr/haberler/mansur-yavas-baskentte-dijitaldonusumu-baslatti/). Ankara Büyükşehir Belediyesi e-belediye uygulamaların geliştirirken toplumsal cinsiyet eşitliğini sağlamaya ve kadınları korumaya çalışmaktadır. Başkent 153 uygulamasındaki mor buton modülü kadınlar için oluşturulmuştur. Açılama yazılabilen, fotoğraf yüklenebilen ve konum bilgisi gönderilebilen butonları vardır. Ayrıca modülün içinde belediyenin kadın danışma birimine ulaşabileceğiniz bir buton da vardır. Buna ek olarak Ankara Büyükşehir Belediyesi; Birleşmiş Milletler Kadın Birimi, İsveç Büyükelçiliği ve Türkiye Ekonomik ve Sosyal Etütler Vakfı (TESEV) iş birliği ile "Mor Haritam" uygulamasını hayata geçirmiştir. Bu uygulama ile Belediyenin kadın merkezleri başta olmak üzere, gündüz bakım evlerine, sosyal yardımlara ve toplumsal cinsiyete dayalı uygulamalara hizla ulaşılabilmektedir. Uygulamanın içeriği ile ilgili olarak Büyükşehir Belediyesi Genel Sekreter Yardımcısı Çokakoğlu; "kadın temelli verilerin alındığ analizlerini yapıyoruz. Bu harita sayesinde kadınlar riskli buldukları bölgeyi bize bildiriyorlar. Kendi mahallelerindeki tüm şiddet merkezlerini, hizmet birimlerini görüp buradan hizmet talep 
edebiliyorlar. Yine harita sayesinde belediyemizin kadınlar için etkin hizmet modellerinin oluşturulmasını sağlayacak eylemler hayata geçiriliyor. Kentteki tüm kadınların ihtiyaçlarını belirleyen ve bu ihtiyaçlar ışında çalışan birimlerimize güç katan bu haritanın Türkiye'de ilk olması bizi ayrıca gururlandırmaktadır. Umarım tüm illerde yaygınlaşır" ifadeleri (https://www.ankara.bel.tr/haberler/mor-haritamuygulamasi-tum-turkiyeye-ilham-kaynagi-olacak/) e-belediye uygulamalarının yaşanabilir bir kent yaratmak için de önemli olduğunu göstermektedir.

\section{Sonuç}

Küreselleşme ve teknolojinin gelişmesi ile birlikte vatandaşların devletlerinden hizmet beklentileri, bu beklentiler doğrultusunda da devletlerin yönetim ve hizmet anlayışları değişmiştir. Vatandaşın beklediği kalitede bir hizmet için bürokrasinin; katı hiyerarşi, gizlilik ve kapalılık, değişime ayak diremeye çalışma, merkezden yönetim, kuralcılık ve sorumluluktan kaçma, aracılar yoluyla işleri yürütme, yolsuzluk ve rüşvet gibi sorunlarının çözülmesi gerektiği kabul edilmiştir. $\mathrm{Bu}$ nedenle teknolojiyi de başat unsur haline getirerek geliştirilen yeni yönetim anlayışında şeffaflık, hesap verebilirlik, vatandaş odaklılık, zamandan ve mekândan bağımsız, fırsat eşitliğini sağlayabilen 7/24 hizmet anlayışı esas alınmıştır. Yeni yönetim anlayışının ise devletler tarafından uygulanması e-devlet ve e-belediye gibi uygulamalarla ile mümkün olabilmiştir. E-devlet ve e-belediye uygulamaları ile vatandaşlar bürokratik engellere takılmadan kamusal hizmetlerden kolayca yararlanabilmektedirler.

Çalışma özelinde e-belediye uygulamasını oldukça etkin kullanan Ankara Büyükşehir Belediyesinin web sitesi ve e-belediye uygulamaları incelenmiştir. Ulaşılan sonuçlarda belediyenin e-belediye hizmetlerinin yeni yönetim anlayışının unsurlarının çoğunu taşıdığı ve bürokrasinin sorunlarını kırmada başarılı olduğu görülmüştür. Ancak hala bazı kurslara ve ihalelere katılmak için başvuruların elden ya da posta aracılığı ile yapılıyor olması zaman kaybı ve kırtasiyeciliği arttıran sorunların devamı olarak görülmüştür. Ancak bunların yanı sıra ihalelerin halka açı yapılması, kaynakların kullanıldığı hizmetlerin 
gösterilmesi, Başkent 153 uygulamasının hem vatandaşlar hem de belediye başkanı tarafından aktif olarak kullanılması bürokratik sorunların çözümü, şeffaf, hesap verebilir, vatandaş odaklı yönetim anlayışının uygulanması ve bürokrasinin katı hiyerarşisinin kırılmasını sağladığ için olumludur. E-devlet ve e-belediye gibi oluşumların kişisel verilerin korunması için kişisel bilgilerin verildiği işlemlerde doğrulama kodlarının olması ya da üyelik istenmesi, bilgi güvenliğini sağlayarak güvenilirliği sağlamakta ve sistemin vatandaşlar tarafından kullanımını arttırmaktadır. Ayrıca ă̆ bağlantılarının hepsinin çalışır durumda olması ve sistemin sürekli güncellenmesi sürekliliği ve verimliliği sağlamak açısından önemlidir.

Ankara Büyükşehir Belediyesinin e-belediye hizmetleri vatandaşların da memnuniyetini arttırmış yeni yönetim anlayışının da gereklerinin birçoğunu yerine getirmiş, zaman ve mekândan bağımsız olarak sürekli hizmet sunumunu sağlamayı hedeflemiş, bürokratik sorunları ve katı hiyerarşiyi ortadan kaldırarak Weber bürokrasinin ve diğer bürokrasi kuramlarının sorunlarına kısmen çözüm olabilmiştir. Ancak e-devletin ya da e-belediyenin bürokrasiyi ortadan kaldırmasının söz konusu olamayacağı açıtır. Çünkü bürokrasi devletin işleyiş şeklidir. Vatandaşların da özünde şikâyet ettikleri hantallık, kırtasiyecilik gibi sorunlar bürokrasinin kendisi değil onun sorunlarıdır. Bu açıdan bakıldığında bürokrasinin ortadan kalkabilmesi için devletin ortadan kalkması gerekmektedir. Bürokrasinin sorunlarının çözülebilmesi için edevlet ve e-belediye gibi uygulamalarla bürokrasi sadece biçim değiştirmektedir. Yeni yönetim anlayışında ise e-bürokrasi oluşmaktadır.

Özellikle pandemi ile birlikte yerel yönetimlere büyük sorumluluklar düşmüş ve Ankara Büyükşehir belediyesi e-belediye uygulamalarını pandemi sürecinden olumsuz etkilenen vatandaşlar için etkili biçimde kullanmıştır. Belediye uygulamaları aracılığı ile yardıma ihtiyacı olan insanlar yardım taleplerini kolayca oluşturabilirken, hayırsever insanların da yardıma ihtiyacı olan insanlara ulaşması daha kolay olmuş böylece e-belediye uygulamalarının sadece bireysel fayda değil toplumsal fayda da sağlayabileceği görülmüştür. Buradan yola çıkarak günümüzde elektronik uygulamaların çoğu zaman erişilebilirlik noktasında hayati önem taşıyabileceği görülmektedir. Buna ek olarak pandemi süresince e-belediye uygulamalarından en fazla tahsilat ve 
sosyal yardım talebi ile ilgili olan işlemlerin yapıldığı öngörülmektedir. Vatandaşlar uzun kuyruklara girmeden, sosyal mesafeyi ihlal etmeden faturalarını evlerinden ödeyebiliyorlarken, belediyeler ise fatura ödeme noktaları oluşturmak ve tahsilatı sağlayacak memur görevlendirmek zorunda kalmamaktadır. Bu durum, vatandaşların hizmetlere zamandan ve mekândan bağımsız ulaşabilmesi, belediyenin ise kırtasiyeciliğinin azalması, ekonomik kaynakları daha etkili kullanabilmesi yönünden olumlu bulunurken, e-belediye hizmetleri ile birlikte görevli memura olan ihtiyacın azalması istihdamı da azalttığı için olumsuz bir etki olarak görülebilmektedir. Ankara Büyükşehir Belediyesinde e- belediye uygulamalarında ise ihale tekliflerinin hala elden ya da posta yoluyla yapılıyor olması zaman kaybı yaratıp kırtasiyeciliği arttırdığı için olumsuz görülmektedir. Buna bir çözüm olarak e-ihale portalının içerisine e-teklif butonu yerleştirilerek ihaleye katılan tarafların birbirlerinin tekliflerini görmeden teklif verebilecekleri, şifreli ve ihale teklifi verme süresinin sinırlı olduğu bir ortam oluşturulabilir. Ankarakart'a kredi kartı ile e-belediye uygulamaları ile yükleme yapılabildiği gibi su kartlarına da kart numarası ile uygulama üzerinden kredi kartı kullanarak su yüklemesi yapılabilir. Bunlara ek olarak çalışmada bahsedilen yardım talepleri, el ver, su ver, afiyet ver gibi uygulamalar ile Mor Haritam uygulaması gibi uygulamalar ile şehrin ve şehirlinin sorunlarına çözüm getirmek hedeflenmiştir. Çünkü e-belediye hizmetleri; sadece tahsilat, abonelik ya da beyan gibi işlemlerden ibaret değildir. Her şeyden önce bu uygulamalar, daha güvenilir, daha yaşanabilir, yardımlaşma ile dayanışmanın hâkim olduğu hemşehrilik bilincinin, yönetişim anlayışının geliştiği bir şehirde yaşamaya katkı sağladığı ve sorunlara hızlı, ulaşılabilir, etkili ve yerinden yönetim anlayışı ile çözümler sunduğu için önemlidir. 
EXTENDED ABSTRACT

\section{Investigation of Ankara Metropolitan Municipality's E-Municipality Applications in the Context of Public Bureaucracy Problems}

Asime Dilara Erdem - Filiz Tufan Emini

Çanakkale Onsekizmart University

Bureaucracy can be defined as impersonal functioning and rules, organized in a structure that narrows as it rises from the bottom up in a society. With the hierarchy created by the institutions within the structure of the state, paperwork increases and it causes time loss for both the service provider and the service recipient. The technological process that started with the invention of the internet in the world in the 21st century has reached points that we cannot even imagine today. Technology and globalization have turned the world into a village. With the development of technology, the borders between states have been removed and communication has become easier. While the development of communication networks and the formation of electronic environments removed nation states from the classical public administration understanding, they destroyed the strict hierarchical order and removed bureaucratic obstacles.

Thanks to the globalization that started in the last quarter of the 19th century and the developing technology in the 20th century, the bureaucratic orientations of the states have also changed. It has been seen that the strict hierarchy, which is one of the main problems of bureaucracy, is no longer effective, the traffic of paperwork makes the bureaucracy very cumbersome and creates obstacles in carrying out the work. For this reason, states, in order to provide faster and more effective services to their citizens; They have switched to a participatory, transparent and accountable new management approach, focused on the needs of their citizens and business people, where users (citizens) can access public services to be provided electronically from different platforms reliably and from a single point, and they have established egovernment systems within the framework of this understanding. One of 
the most important concepts brought by the new management approach and globalization developed to reduce the problems of bureaucracy is governance. In general, services and reaching citizens; It is defined as the shift from central governments to local governments.

The practices of the municipalities, which are the closest local government units to the public, are important in terms of enabling the people to reach them more easily and to benefit from the services or to voice their complaints. For this reason, e-municipality was brought to the fore in the study, and in this context, the e-municipality applications of Ankara Metropolitan Municipality were searched on the websites, the Başkent 153 application was examined and it was examined whether it could solve the problems of bureaucracy. In the results, it has been seen that the e-municipality services of the municipality carry most of the elements of the new management approach and are successful in breaking the problems of bureaucracy. However, the fact that applications for participating in some courses and tenders are made by hand or by mail is seen as a waste of time and a continuation of the problems that increase paperwork. However, in addition to these, it is positive that the tenders are made open to the public, the services where resources are used, the active use of the Başkent 153 application by both the citizens and the mayor, the solution of bureaucratic problems, the implementation of a transparent, accountable, citizen-oriented management approach and the breaking of the rigid hierarchy of the bureaucracy.

Ankara Metropolitan Municipality's e-municipality services have increased the satisfaction of citizens and fulfilled many of the requirements of the new management approach, aimed to provide continuous service regardless of time and space, and partially solved the problems of Weber bureaucracy and other bureaucracy theories by eliminating bureaucratic problems and rigid hierarchy. Especially with the pandemic, great responsibilities have fallen to local governments and Ankara Metropolitan Municipality has effectively used e-municipality applications for citizens who have been negatively affected by the pandemic process. While people in need of help can easily create their requests for help through municipal applications, it has been easier for charitable people to reach people who need help, so it has been seen that 
e-municipality applications can provide not only individual benefit but also social benefit. From this point of view, it is seen that electronic applications can often be vital in terms of accessibility. In addition, it is predicted that the most transactions related to collection and social assistance requests from e-municipality applications are made during the pandemic. While citizens can pay their bills from their homes without queuing and violating social distancing, municipalities do not have to create bill payment points and appoint officers to ensure the collection. This situation is considered positive in that citizens can access services independently of time and place, while the municipality's paperwork is reduced and it can use economic resources more effectively.

\section{Kaynakça / References}

Acılar, A. (2012). Küçük şehir belediyelerinde web sitesi ve e-belediye kullanımı: Bilecik belediyesi örneği. DPUJJS, 32(1), 125-142.

Akçakaya, M. (2016). Weber'in bürokrasi kuramının bugünü ve geleceği. Gazi Üniversitesi Sosyal Bilimler Dergisi Özel Sayısı, 3(8), 275-295.

Akçakaya, M. (2016a). Bürokrasi kuramları ve Türk kamu yönetiminde bürokratik sorunlar. Gazi Üniversitesi Iktisadi ve İdari Bilimler Fakültesi Dergisi, 18(3), 669-694.

Aksan, G. ve Çelik, Ö. (2011). Gerilim ve uzlaşma: Bürokrasi ekseninde bürokrasi ve siyaset ilişkisi üzerine bir değerlendirme. Selçuk Üniversitesi Sosyal Bilimler Enstitüsü Dergisi, 25, 1-10.

Aktan, C.C. (2011). Devletin büyümesi ve devletin başarısızlığının anatomisi. Hukuk ve İktisat Araştırmalarn Dergisi, 3(1), 29-49.

Arslan, D. A. (2008). Eşitsizliğin teorik temelleri: Elit Teorisi. Kocaeli Üniversitesi Sosyal Bilimler Enstitüsü Dergisi, 6, 115-135.

ASKI Genel Müdürlüğü (2021), Bilgi talebi hakkında dilekçe cevabı. Belgeyi Sorgulamak için https://ebyssorgu.aski.gov.tr/, Belge Doğrulama Kodu: 0DHT-PPLE-0271

Aydın, N. (2012). Weberyen bürokraside liyakat ve türk kamu bürokrasisinden bir kesit: Siyasetin Bürokrasi İronisi. Sayıştay Dergisi, 85, 51-67.

Aydilek, E. (2019). Türk siyasal hayatında bürokrasi- siyaset ilişkisi. Kastamonu İletişim Araştırmaları Dergisi, 3, 57-72. 
Çakır, M. (2014). Bürokrasi ve suç olgusu. KMÜ Sosyal ve Ekonomik Araştırmalar Dergisi, 16(Özel Sayı 1), 18-24.

Çakır, C. (2015). E-Belediye: Sorunlar ve çözüm önerileri. Sosyal ve Beşeri Bilimler Dergisi, 7(1), 1-15.

Çarıkçı, O. (2010). Türkiye' de E-Devlet uygulamaları üzerine bir araştırma. Süleyman Demirel Üniversitesi Sosyal Bilimler Enstitüsü Dergisi, 2(12), 95-122.

Çevikbaş, R. (2006). Yönetimde etik ve yozlaşma. İktisadi ve İdari Bilimler Dergisi, 20(1), 265-289.

Demirel, D. (2006). E-Devlet ve dünya örnekleri. Sayıştay Dergisi, 61, 83- 118.

DPT, (2009), Stratejik plan (2009-2013). 1-124.

Dursun, D. (1992). Bürokrasi Teorisi ve yönetim. Sosyal Siyaset Konferansları Dergisi, (37-38), 133-149.

Efendioğlu, A. ve Sezgin, E. (2007). E-Devlet uygulamalarında bilgi ve paylaşım güvenliği. Ç.Ü Sosyal Bilimler Enstitüsü Dergisi, 16(2), 219236.

Erdoğan, C. (2018). Cumhuriyet Halk Partisi'nin Antalya üyelerinin parti içi demokrasi ve oligarşiye bakış açısı. Akdeniz İ̈BF Dergisi, 37, 63-87.

Erdoğan, O. (2019). Yerel yönetimlerde E-Belediye uygulamaları. Süleyman Demirel Üniversitesi İktisadi ve İdari Bilimler Fakültesi Dergisi, 23(3), 551-566.

Eryılmaz, B. (2015). Kamu yönetimi, (8.Baskı), Kocaeli: Umuttepe Yayınları.

Gökçe, O ve Şahin, A. (2002). 21. yüzyılda Türk bürokrasisinin sorunları ve çözüm önerileri. Sosyal Ekonomik Araştırmalar Dergisi, 2(3) , 1-27.

Hazman G., G. (2005). Afyonkarahisar Belediyesinde e-Belediye uygulamaları ve yerel farkındalık. Afyon Kocatepe Üniversitesi İktisadi ve İdari Bilimler Fakültesi Dergisi, 3(2), 65-84.

Kırışık, F. (2013). Kamu yönetiminde küresel değişimler ve yeni sorun alanları. Dumlupınar Üniversitesi Sosyal Bilimler Dergisi, 38, 285-295.

Koçak, S.Y. (2010). Kamu yönetiminde açıklık için bilgi edinme hakkı. Selçuk Üniversitesi Sosyal Bilimler Enstitüsü Dergisi, 23, 115-125.

Metin, A. (2012). Türkiye'de E-Devletin uygulanması ve E-Devletin bürokrasiye etkisi. Dicle Üniversitesi Sosyal Bilimler Enstitüsü Dergisi, 4(7), 97-108.

Ökmen, M. ve Canan, K. (2009). Avrupa Birliği'ne üyelik sürecinde Türk kamu yönetimi. Yönetim ve Ekonomi, 16(1), 139-171. 
Önal, H.İ. ve Alaca, E. (2017). Vatandaşlık okuryazarlığı çerçevesinde EBelediye uygulamalarının değerlendirilmesi. Bilgi Dünyası, 18(1), 93-124.

Özer, M.A. (2005). Günümüzün yükselen değeri: Yeni kamu yönetimi. Sayıştay Dergisi, 59, 3-46.

Selçuk, E. (2010). Kamu yönetimi. İstanbul Üniversitesi Açık ve Uzaktan Eğitim Fakültesi Ders Kitabı.

Sezer, Ö. (2008). Kamu hizmetlerinde müşteri (Vatandaş) odaklıllk: Türkiye'de kamu hizmeti anlayışı açısından bir değerlendirme. ZKÜ Sosyal Bilimler Dergisi, 4(8), 147-171.

Şahin, A.(1998). Bürokrasi kuramı ve türk bürokrasisi. Yüksek Lisans Tezi. Selçuk Üniversitesi Sosyal Bilimler Enstitüsü, Kamu Yönetimi Bilim Dalı, Selçuk Üniversitesi, Konya.

Şahin, A. ve Örselli, E. (2003). E-Devlet anlayışı sürecinde Türkiye. Selçuk Üniversitesi Sosyal Bilimler Enstitüsü Dergisi, 9 , 321-342.

Yıldırım, U. ve Öner, Ş. (2004). bilgi toplumu sürecinde yerel yönetimlerde eğitim bilişim teknolojisinden yararlanma: Türkiye'de E-Belediye uygulamaları. The Turkish Online Journal Of Educational Technology (TOJET), 3(1), 49-60.

Yılmaz, A. ve Kılavuz, R. (2002). Türk kamu bürokrasisinin işlemsel sorunları üzerine notlar. C.Ü İktisadi ve İdari Bilimler Dergisi, 3(2), 1731.

\section{Internet Kaynakları}

www.belediye.gov.tr/belediyelerde-devrim-niteliginde-uygulama (Erişim Tarihi: 22.05.2020).

https://www.ankara.bel.tr/ (Erişim Tarihi: 22.05.2020).

https://www.ankara.bel.tr/baskan/baskana-mesaj (Erişim Tarihi: 22.05.2020). https://www.ankara.bel.tr/sosyal-hizmetler (Erişim Tarihi: 23.05.2020). https://www.ankara.bel.tr/kulturel-hizmetler ( Erişim Tarihi: 23.05.2020). https://www.ankara.bel.tr/saydamlik-ve-hesapverilebilirlik (Erişim Tarihi: 23.05.2020).

https://www.haber3.com/yerel/ankara-buyuksehir-belediyesi-ihaleleri-canliyayinliyor-haberi-5033943 (Erişim Tarihi: 24.05.2020).

https://www.ankara.bel.tr/ihale-duyurular (Erişim Tarihi: 23.05.2020).

https://www.ankara.bel.tr/buyuksehir-bugun-ne-yapiyor (Erişim Tarihi: 23.05.2020).

https://www.ankara.bel.tr/etkinlik-takvimi (Erişim Tarihi: 23.05.2020). 
http://map.ego.gov.tr:8080/ego/index.aspx (Erişim Tarihi: 23.05.2020). https://mebis.ankara.bel.tr/ (Erişim Tarihi: 23.05.2020).

https://tahsilat.ankara.bel.tr/OnlineTahsilat/sicilsorgu.htm (Erişim Tarihi: 24.05.2020).

https://www.ankara.bel.tr/index.php?cID=2123/ (Erişim Tarihi: 23.05.2020). https://onlineislem.aski.gov.tr/ (Erişim Tarihi: 24.05.2020). https://mavimasa.ankara.bel.tr/ (Erişim Tarihi: 23.05.2020). https://mavimasa.ankara.bel.tr/WebBasvuru\#/ (Erişim Tarihi: 23.05.2020). https://play.google.com/store/apps/details?id=tr.bel.ankara.baskentmobil\&hl $=\operatorname{tr}$ (Erişim Tarihi: 23.05.2020).

https://www.hurriyet.com.tr/yerel-haberler/ankara/mavi-masa-mobilhizmet-verecek-41426010 ( Erişim Tarihi: 23.05.2020).

https://www.aa.com.tr/tr/turkiye/baskent-mobil-uygulamasitanitildi/1734213 (Erişim Tarihi: 24.05.2020).

https://www.haber3.com/yerel/ankarada-alo-153-mavi-masa-yenilendi-yeniadi-baskent-153-haberi-5087308 (Erişim Tarihi: 24.05.2020).

https://www.cumhuriyet.com.tr/haber/ankara-buyuksehir-belediye-baskaniyavas-cilgin-projesini-acikladi-1717948 (Erişim Tarihi: 24.05.2020).

https://www.milliyet.com.tr/yerel-haberler/ankara/alo-153-mavi-masadamemnuniyet-orani-yukseldi-6127931 (Erişim Tarihi: 24.05.2020).

https://www.memurlar.net/haber/871354/mansur-yavas-halk-market-inadini-degistirecegiz.html (Erişim Tarihi: 24.05.2020).

https://www.ankara.bel.tr/haberler/baskan-yavastan-kadina-siddete-karsimor-buton (Erişim Tarihi: 09.06.2020).

http://www.ankara.bel.tr/haberler/baskan-yavastan-su-faturalarindaduzenleme/ (Erişim Tarihi: 19.06.2020).

https://www.instagram.com/ankarabbld/ (Erişim Tarihi: 19.06.2020).

https://www.ankaratekyurek.com/ (Erişim Tarihi: 31.05.2021).

https://suver.aski.gov.tr/ (Erişim Tarihi: 31.05.2021).

https://biletver.ego.gov.tr/ (Erişim Tarihi: 31.05.2021).

https://www.iftarver.com/ (Erişim Tarihi: 31.05.2021).

https://www.afiyetver.com/ (Erişim Tarihi: 31.05.2021).

https://ankaratekyurek.com/elver.php (Erişim Tarihi: 31.05.2021).

https://www.ankara.bel.tr/haberler/mansur-yavas-baskentte-dijitaldonusumu-baslatti/ (Erişim Tarihi: 31.05.2021).

https://www.ankara.bel.tr/haberler/mor-haritam-uygulamasi-tumturkiyeye-ilham-kaynagi-olacak/ (Erişim Tarihi: 03.06.2021). 


\section{Kaynakça Bilgisi / Citation Information}

Erdem, A. D. ve Emini, F. T. (2021). Ankara Büyükşehir Belediyesinin EBelediye uygulamalarının kamu bürokrasisinin sorunları bağlamında incelenmesi. OPUS-Uluslararası Toplum Araştırmaları Dergisi, 18(Yönetim ve Organizasyon Özel Say1s1), 1909-1942. DOI: $10.26466 /$ opus.846600. 